\title{
COMMUNICATION OF PUBLIC, PRIVATE AND CIVIL SECTOR IN MIGRATION CRISIS
}

\author{
Ivan Nađ, Ph.D. \\ University of Applied Sciences Velika Gorica \\ E-mail: ivan.nadj@vvg.hr \\ Ana Mirenić, Exp. Spec. Oec. \\ University of Applied Sciences Velika Gorica \\ E-mail: ana.mirenic@vvg.hr
}

\begin{abstract}
The migration crisis faced for the first time on a larger scale by the Republic of Croatia in the second half of the year 2015 , has in fact only scratched our country and the public has been receiving information every day through radio, newspapers, and television reports which informed only poorly about what was actually happening on refugee routes and in refugee camps. Special attention in informing the public was directed to the issues of reasons why the borders were closing and the barriers were rising on the borders of certain countries in our environment. Everyday reports mentioned the countries from Turkey via Greece, Italy, Macedonia, Serbia, and Austria, Slovenia and Hungary as well as the island of Lesbos, over which the migrants from the East were leaving their countries because of the war and famine, all in the desire to have a better life in the developed European countries. A number of organizations from the civil, private and public sector participated in accordance with their authorities in the organization and accommodation of refugees who were in transit through the Republic of Croatia. The paper analyses the roles and specific characteristics of the public and private, as well as civil sector, related to the precision and timeliness of the communication within these bodies and informing the wider social community about the events related to the migrant crisis. The research analyses the importance of precise and timely information both for the migrants as well as for the entire social environment with the aim of reducing the possible consequences resulting from the migration crisis.
\end{abstract}

Key words: communication, public sector, private sector, civil sector, migration crisis 


\section{Security}

\section{INTRODUCTION}

Migrations of the human society have been present throughout the entire history of humankind. Migrations have been an integral part of the human civilisation. The problems of today's society, wars, economic crises, natural disasters are even today the cause of major migrations, emigration from one to another country and settling in other parts of the world.

However, migrations that have marked our time as well, and our society is the migration crisis that began in 2015 and has been ongoing today, i.e. regaining its intensity.

A number of organisations were involved in the accommodation of refugees on the Croatian territory. All of them contributed in some way for the information about the refugees, their lives, limitations and requests to reach every human being. The greatest role here is of the media as a mediator between those inside and those outside the camp.

Along the severe problems provoked always by migration crises, precise information and high-quality communication can greatly contribute to their maximally successful resolution, but can otherwise cause major damage.

\section{BASIC CHARACTERISTICS OF MIGRATION CRISIS}

During the refugee crisis in two years (2015 and 2016) more than a million refugees arrived in Europe. Apart from war, people from the East flee also because of poverty in the war-torn countries, lack of basic living conditions, such as employment or health care, lack of educational opportunities, as well as because of the general loss of hope in the better tomorrow. On the one hand all the above, and on the other hand, pictures of a happy and successful Europe where they can find everything they lack are maybe the main reasons why numerous Syrians and members of other people saw a sufficiently good reason to embark on an extremely dangerous adventure - a trip to the countries of Western Europe.

Numerous open issues occur in migration crises, which include the impact of globalisation on the migration flows, the regulation of the legal position of the foreign migrants on the international area, migration policy, entry, movement and stay of the foreign nationals in some areas, as well as their integration into a new society. There are also issues of protecting the refugees and asylum seekers.

The Republic of Croatia has also faced all these issues, and we may say that she has been successful in handling them so far. The National Security Strategy of the Republic of Croatia ${ }^{66}$, adopted based on Article 81 of the Constitution of the Republic of Croatia67, by the Croatian

\footnotetext{
${ }^{66}$ The National Security Strategy of the Republic of Croatia, adopted based on Article 81 of the Constitution of the Republic of Croatia, by the Croatian Parliament at its Session on 14 July 2017.

${ }^{67}$ The Constitution of the Republic of Croatia is a unique general legal act with the highest legal power in the Republic of Croatia which contains the predominant number of constitution-legal norms. It was brought by the Croatian Parliament
} 
Parliament, among other things states: "By its own activities, in interaction with numerous international processes, a high level of security has been achieved that provides a balanced development. However, external and internal threats, risks and challenges change continuously and rapidly, they are highly complex, related and often unpredictable, creating the need for constant development of national security policy and ability to respond to changes. In today's world the internal and external aspects of security are strongly connected and this affects our commitment to a comprehensive approach to achieving the security goals.", (Croatian parliament, 2017).

The National Security Strategy further explains that there is danger of various external impacts that affect our area as well. "Since the beginning of the conflict in Syria and Iraq, more than a hundred people from South-eastern Europe joined the terrorist organisations active in the areas of war conflicts. Their return to motherhood countries increases the risk of terrorism and for the Republic of Croatia. Threat is represented also by the self-radicalised individuals who are not in direct contact with the terrorist organisations, but under the influence of terrorist propaganda they could perform individual terrorist attacks. Strengthening radical nationalism based on the state-of-the-art ideologies, including ideas about changes in the internationally recognised borders, as well as the activities aimed at violating the credibility of the Republic of Croatia, and endanger the security, interests and reputation of the Republic of Croatia and endanger the survival and position of the Croats in the South-eastern neighbourhood." (Croatian parliament, 2017).

It is precisely these facts that reinforce the fear of newcomers arriving from the East, often associating them with terrorism happening across Europe in the recent years. The Republic of Croatia has therefore become actively involved in the protection of its own borders, fulfilling thus also the requirements set as a condition for accessing the "Shengen"68 area. On the other hand, at the beginning of the refugee crisis, refugee camps have been built in Opatovac near Tovarnik and in Slavonski Brod, and the state insitutions became involved in the process of receiving, assisting as well as integrating foreign nationals who received international protection and right of residence in the Republic of Croatia.

Despite the efforts to prevent them, Croatia was faced also with illegal crossings of its borders, that have been unfortunately intensified lately.

on 22 December 1990, and it is called the Christmas Constitution. It contains 152 articles in X sections, and therefore and because of the length belongs to one of a shorter Constitutions.

Original text of the Constitution had 142 articles in IX. Sections. The first modification of the Constitution took place on 18 December 1997 by the Constitution Law on modifications and amendments of the Constitution of the Republic of Croatia. A significant revision of the Constitution occurred also on 9 November 2000. New revisions followed in March 2001, and after that the refined text of the Constitution and minor corrections was published. The latest modification was done on 11 December 2013 by the amendment on Article 61, defining marriage as a living community of a male and female.

${ }^{68}$ Schengen area includes a territory of 26 European countries that adopted the Schengen agreement, signed in 1985 in Schengen, Luxembourg. The Schengen area covers 4,312,000 km². 


\section{Security}

"Some states, members of the Union, which have marked in various ways this migration crisis are certainly Germany, Sweden, Italy, Greece, and Hungary. Thanks to the "open door" approach Germany "invited" the migrants to accept her hospitality and protection. During this crisis Sweden received most migrants in relation to the number of residents in their own country. Italy has for years almost completely alone dealt with big daily inflow of migrants to the Italian coast (this trend has continued this year after the route across Greece is almost closed). In 2016 only, more than 350,000 migrants arrived in Italy. As far as Greece is concerned, although being a member of the European Union and the Schengen area, the it seems it has done very little in controlling the migration flow and preventing illegal migrations across its territory... In comparison with other European Union member states, Hungary has largely securitized the issue of mass migrations by laying wire towards the neighbours, but only after months of trying to resolve this issue at the European level.", (Mikac, Dragović, 2017).

\section{ROLE OF PUBLIC SECTOR IN REFUGEE CRISIS}

Entire Europe has faced the problems of refugees. Therefore, the topic of the Council of Europe Congress meeting ${ }^{69}$ at the end of March 2017 was the issue of refugees leaving the waraffected areas and seeing their rescue on the European soil. "From the very beginning it has been clear that the refugee crisis as an unprecedented event requires adequate response from the local and regional authorities in Europe, crucial for effective action in the field. The refugee crisis is at the same time a public policy crisis," as concluded in Strasbourg. Since Turkey is the state that has a significant impact on the movement of refugees, the representatives of the Council of Europe carried out in that country a fact finding mission in late 2016 and based on the observed facts brought a recommendation to the Committee of Ministers to invite the Turkish authorities to align their legislation related to terrorism and the treatment of the arrestees with the European Charter on Human Rights and the European Standards. Since 2012, the European countries have marked an increased inflow of refugees culminating in 2015 when 1.3 million asylum seekers came to Europe and about 3.1 million to Turkey.", (Association of Municipalities in the Republic of Croatia, 2018).

\footnotetext{
69 The Council of Europe, French: Conseil de l'Europe, German: Europarat) is an international organization of 47 member states of a wider European region, with the main tasks to strengthen the democracy, protect the human rights and legal state on the European continent. The biggest scope of the Council of Europe is reflected in the European convention on human rights, signed in 1950, which serves as the basic legal document to the European Court for human rights.

The headquarters of the Council of Europe is in Strasbourg on the French-German border. The first headquarters was in the Strasbourg University Palace whereas now it is situated in the Palais de l'Europe (Palace of Europe). Membership in the Council of Europe is open to all European democratic states that have accepted the principle of the rule of law, multi-party democracy, guaranteeing the basic human rights and freedom to all their citizens.

The Council of Europe should not be mixed with the European Union Council or European Council that are in fact the European Union bodies. The Council of Europe is an independent international organization separate from the European Union.
} 
In the report on solving the issue of the movement of refugees and migrants: The role of external activities of EU Committee for Development and the Committee for external affairs of the European Parliament ${ }^{70}$ states that these committees in the mentioned chapters provide the following instructions:

- emphasises that all possible measures need to be undertaken in order to guarantee the refugees decent living conditions within the member states and in the refugee camps, particularly regarding health care, education and work opportunities;

- condemns the drastic number of deaths of migrants in the Mediterranean Sea and expresses concern about the increasing number of violations of human rights of the migrants and asylum seekers on their journey towards Europe;

- expresses great concern due to the large number of cases ofjuvenile migrant disappearances without escort; calls on the Commission and member states to establish a database on unaccompanied minors who have entered the territory of the member states;

- commends the work that, despite all the difficulties and dangers, carried out by the local and international non-governmental organisations and organisations of civil society in providing emergency, and in many cases rescue assistance to the most vulnerable people in the countries of origin, transit or destination countries of the refugees and migrants; points out that their efforts in numerous cases have filled the gap left by the states and the wider international community;

- considers that it is crucial to overcome the current discourse presenting the refugees exclusively as a burden and emphasises that the refugees, if they get a chance, can positively contribute to the community hosts; recommends the inclusion of refugees in defining and shaping of political responses that have direct impact on them and in creating or strengthening the necessary programs; invites the European institutions and agencies to launch within their administrations internship programs particularly oriented to young refugees with university diplomas who are legally residing in the European Union so as to show on their example the benefits of investing in younger generations, (European Parliament, 2017).

The Croatian public services, competent ministries, all the way to the units of local selfgovernment, each in the area in which they have their authorities, have given their contribution.

"During 2015 Croatia made several important moves in the human relationship to the refugees who were passing through the Balkan route. For the start it was the first to introduce free trains for their transportation from border to border, unsuccessfully trying to persuade other countries to accept this model. Slovenia accepted it in a later phase, Serbia due to infrastructure and other restrictions did not, whereas Macedonia was charging the state train tickets.... By building a winter transit centre in Slavonski Brod the Croatian government provided the refugees with more acceptable conditions for rest in days when the throughflow of people was at its highest,

${ }_{70}$ The European Parliament is the only directly elected body of the European Union that together with the Council of Ministers makes the legal authority of the European Union. It consists of 766 representatives, who are elected every five years and represent 500 million citizens of Europe. 
but the tents were mostly empty because the intention was to get the refugees to leave the country as fast as possible. This was especially felt in the months in which the closure of borders was suspected, and the people were registered and directed further as if on a conveyor belt so that they would not be left to the care of the Republic of Croatia at the moment of the route closure. Even after Hungary and Slovenia blocked their borders, Croatia kept repeating that the only reasonable solution is to allow unimpeded flow of refugees towards their desired destinations. Unfortunately, there was not often mention of the possibility of seeking asylum in our country, but, to be frank, the majority of refugees were not even interested in staying in unpersepective Croatia, (Tadić, Zajović, 2017).

\section{ROLE OF CIVIL SECTOR IN REFUGEE CRISIS}

“Democratic societies are characterised by co-existence of three sectors: public (state), private (market) and civil (civil society). The civil society consists of citizens who actively and freely get involved in all spheres of social activities. ", (Tomašić, 2015).

The assistance to the arrival of refugees to Croatia, apart from the public sector, was also offered by the civilian organisations as well as numerous humanitarian organisations. All of them gave their contribution to helping everyone in their own way to the afflicted people. For instance, the Institute for the Development of Education ${ }^{71}$ joined the initiative of the civil society "Welcome!"72 within which the action was taken to create education policies according to the refugees' needs who make up one of the most vulnerable groups of every society. "The aim of advocacy activities is to contribute to the creation of mechanisms that would allow refugees who stay in Croatia successful integration into the Croatian higher education as well as recognition of the previously acquired qualifications in order to enter the higher education system or to continue studying and getting employment.

In the recent weeks we have been witnessing a situation in which thousands of people from the conflicting zones are risking their lives and lives of their children in order ${ }^{73}$ to arrive in the

\footnotetext{
71 Institute for Education Development (IRO) was founded in 1999 as a non-for-profit organisation addicted to development, advocation and carrying out of the policies of higher education in Croatia. IRO has been for sixteen years already dealing systematically with higher education, especially in the areas of higher education funding, equalities of accessing higher education, connecting higher education with the labour market and academic mobility.

72 Initiative for the support of refugees "Welcome" gathers individuals and organisations of the civil society with the aim of providing support to the refugees in the field, as well as performing political pressure on the institutions of the Republic of Croatia and the European Union in order to change the migration policies. The Initiative gathers more than 60 organisations of the civil society, one football club and over 400 volunteers who provide support to refugees every day in the field - from humanitarian help, coordination with local organisations, as well as provision of information to refugees about actual procedures of entering and exiting from Croatia.

${ }^{73}$ The manager of the project is the Association "MI" (WE) from Split, whereas the partners are: Voluntary centre from Hungary (OKA), Croatian Network of Voluntary Centres, Voluntary Centre Sheffield, Society Legis Skopje, Novi Sad
} 
European Union in the hope of finding a safe refuge. Although at this moment the most important focus is on direct provision of humanitarian aid to refugees and providing a safe passage so that they would reach the planned destinations, it is important to begin to actively reflect on integration policies in order to enable these people to continue living in the most painless and simpler way in their new homes.", (Institute for the Development of Education, 2015).

In order to prepare as best as possible for the possible new arrival of refugees, the civil society associations who work with volunteers and refugees as part of their project held at the beginning of the last year 2017 the first international conference entitled "Optimizing volunteer services in times of refugee crisis ", funded by the EU funds - EU Program for citizens. The Institute for migrations and nationalities gave recommendations for the development of integration policies and measures in the Republic of Croatia:, (Institute for Migrations and Nationalities, 2016).

- make an information leaflet about the integration of immigrants in Croatia, about the rights and obligations and the institutional support to immigrants in the Republic of Croatia (institutional guide to integration);

- revise and adapt the integration conditions to gain the rights for permanent residence;

- equalize the criteria for gaining Croatian citizenship for all categories of foreigners who live, work and educate themselves in the Republic of Croatia;

- improve the scheme of integration courses for foreigners;

- include in the National Frame Curriculum for pre-school education and education as well mandatory secondary education of several inter-cultural programs and place stronger emphasis on strengthening the citizenship competences;

- enable free attendance of language courses in order to provide easier coping within the society and inclusion in the labour market to persons under international protection as an especially vulnerable group of foreigners in the Republic of Croatia;

- allow a more adequate access to professional qualifications and grants to citizens of the third countries;

- enable wider political participation of immigrants, especially of the citizens of the third countries, and widening the right to vote at the local level to persons with approved permanent residence;

- ensure a wider scope of the right to medical care to especially vulnerable groups of migrants among irregular migrants and asylum seekers;

- financially and strategically support the activities of immigrant societies;

- improve the national plan and measures of suppressing discrimination, xenophobia, and racism, and promote tolerance, solidarity and humanity through public policies and media;

- develop cultural and gender-specific integration measures; 
- stimulate and develop intra-departmental and inter-departmental cooperation of the responsible institutions with local communities and organizations of the civil society, academic community and representatives of the migrants. ${ }^{74}$

\section{ROLE OF THE MEDIA IN REFUGEE CRISIS}

The terrorist attacks are nothing new in the world. However, in the recent decade they have marked forever the major European cities such as Paris and Brussels, London. Berlin and Barcelona. The increase of fatalities connected with terrorism ${ }^{75}$, according to the research of the Institute for Economics and Peace, increased in 2014 by as much as 45 percent. During the creation of schematic organizational functions of terrorism the fundamental task is done by mass media and numerous social networks. Unfortunately, the media use terrorism as topics that increase the ratings and flow of information, thus ensuring to terrorist organizations precisely what they need - spreading of their political messages. It is because of the media that dramatic and shocking news, photos and recordings directly reach the public. Media thus published the news about the deaths of migrants, and the news were so frequent that they could be hardly followed. Thus from Večernji list (Bohutinski, 2015), that conveyed the information of the International Organization for Migrations ${ }^{76}$, informing that until September 2015 there were 3,423 migrants who lost their lives by trying to reach the European coasts. This refers primarily to Italy, Greece, Malta and Spain.

This is a number that exceeded the number of fatalities of migrants in 2014 which was 3,279 , and most people fell as victims in the so-called central Mediterranean route between North Africa and the coast of Italy and Malta. Thus in one day only, in April 2015 this route took lives of 800 people in the sea. Their rescue included many volunteers, so that the Institute for Migrations and Nationalities published that about 150,000 refugees were rescued in the operation Mare Nostrum on the Mediterranean. ${ }^{77}$

After the Agency for the Protection of External border of EU, Frontex (actions Poseidon and Triton) took over the authority of continuing the operation in October 2014, the actions continued,

\footnotetext{
${ }^{74}$ Because of terrorist actions in 2014 a total of 52.9 billion of dollars were spent throughout the world. Last year the number of fatalities related to terrorism increased significantly, and it reached almost 32,700 , which is by 18,000 more than the previous year.

${ }^{75}$ Institute for Economics and Peace has its headquarters in Sidney, Australia.

${ }^{76}$ (International Organisation for Migrations, abbr: IOM) is an international humanitarian organization dealing with all aspects of migrations. It was founded in 1951 as an Intergovernmental Committee for European Migrations (ICEM) and it referred only to European migrations, and later, acting towards the regions of the world, it encompassed the problems of migrations on all continents. IOM currently has 157 members' states and 10 observer states.

77 The Mare Nostrum Operation (Our Sea) is the title for a one-year rescue operation of the Italian coast guard and navy, that lasted from 13 0ctober 2013 to 31 0ctober 2014. The operation was carried out with the aim of rescuing the immigrants who tried to reach Italy over the Mediterranean Sea during the migration crisis. During the action over 150,000 immigrants from the area of North Africa and the Near East have been rescued. The rescuing of immigrant was carried out on the sea belt around the Italian island of Lampedusa.
} 
but exclusively as patrolling and controlling and returning the ships to the coasts of North Africa. It is namely, that until the beginning of November 2015 there were about 770 thousand of people who arrived in Europe, leaving their homes. The largest number arrived in Greece, about 620 thousand people.

After closing the Hungarian borders, the refugees arrived in Croatia via the so-called Balkan route that was a continuation of the East-Mediterranean route that was mainly taken by the refugees from Syria, Iraq and Afghanistan. Croatia mainly had the role of a transit country, and the Balkan route was closed on 8 March 2016.

The perception of refugees, their journey, doubts and justifications in the wide public is mainly formed by the media. Based on the television broadcasts, radio broadcasts, texts, news, photos, Internet... an image is formed about something that we cannot see, experience or feel first hand.

\section{RESEARCH}

\subsection{Depth interview}

Depth interviews have been conducted for the purpose of this paper with 13 persons (eleven questions equal for all) show a high level of the lack of trust towards the refugees, but also readiness to help. The interviews were conducted with the persons within the age of 25 and 65 .

Questions sent on-line to web-application Microsoft Forms were as follows:

1. In your opinion - who is a refugee?

2. Have you got understanding for the refugees?

3. Do you think the borders should be closed to refugees?

4. Would you be ready to help them?

5. Do you think their human rights have been endangered?

6. Are you prone to relate refugees with terrorist attacks?

7. Do you believe that refugees are people who leave their homes with a reason?

8. Do you think that Europe has accepted the refugees adequately?

9. What would you change in receiving the refugees?

10. How did you receive information related to refugees?

11. Do you believe the media regarding information about the refugees? 


\section{Secuurity}

\section{Answers:}

\section{In your opinion - who is a refugee?}

- People who flee from their homeland due to a certain crisis, war mainly.

- Persons who flee from their homes and homeland.

- I think refugees are people who have been expelled by war from their homes.

- For me, refugees are people running from their countries due to certain crisis, mainly war.

- People, who because of impossibility to live in their own home and own homeland are forced to look for the possibility of normal living in another environment.

- Persons expelled from their country because of their nationality, race or political option that they support, i.e. persons who fearing for their lives in the war-afflicted area, leave their homes, going to more peaceful areas close to their culture, hoping to return home after the end of war. Similar to what e.g. the exiled Vukovar people were in the Homeland War.

- I think that refugees are persons who for some economic, social, health or security reasons left their residence and their country and settled in some other country.

- I think refugees are people who were expelled by war from their homes.

- People who have been forced to leave their homes.

- People like everyone else, but those who at that moment in their lives need great help and understanding from other people.

- Persons who due to various circumstances are forced to leave their country.

- Persons just like myself, but having unfortunate fate.

- People who left their countries due to difficult living conditions, war ...

\section{Have you got understanding for the refugees?}

- Yes.

- I have understanding for the refugees, if these involve children, women and old people.

- I have understanding for the refugees.

- I have understanding, but not for all groups.

- I have understanding since we also went through this, but for mothers with children and old people.

- For refugees yes, but not for economic migrants.

- I support those for whom this is the only way to avoid a life threat, not those who leave due to economic reasons since they should be looking for a legal way.

- Yes.

- Yes, however, our understanding does not solve the origin of the refugees' problem.

- No.

- Yes. 
- Absolutely.

- Not really.

\section{Do you think the borders should be closed to refugees?}

- I am not for closing the borders, but I am for controlling of the entry of persons into the country so that it is clear who entered the country, whether in transit or staying and what they are doing.

- I would close the borders to certain categories (military capable men).

- Yes, I am for closing the borders.

- I agree with those who consider that the borders should be closed.

- Yes.

- Yes, to economic migrants who represent themselves as refugees.

- No.

- In some cases - YES!

- Yes.

- No.

- Yes.

- Yes.

- No way and never.

\section{Would you be ready to help them?}

- Certainly.

- I would help mothers with little babies.

- I am not ready to help.

- I would help them.

- Only mothers with children.

- Not migrants.

- No.

- Yes, I am ready to help the migrants.

- Yes.

- Yes.

- Yes.

- No.

- No. 


\section{Do you think their human rights have been endangered?}

- Yes.

- I think their human rights have been endangered.

- Yes.

- Yes.

- Yes

- Very endangered.

- I think their human rights have been endangered.

- Yes, their human rights have been endangered.

- Certainly, their human rights have been endangered and much more than this.

- Yes.

- I am sure.

- Principally yes, because they have no right to normal lives.

- No.

\section{Are you prone to connect refugees with terrorist attacks?}

- No.

- Yes, I relate refugees to terrorist attacks.

- Yes, I connect them with terrorism.

- Yes, all is possible.

- Yes, I connect them with terrorist attacks.

- I am afraid, yes.

- No, terrorists do not arrive in refugee lines.

- Yes.

- No.

- Yes.

- Yes.

- I do not relate them to terrorists, although this is not always so.

- Certainly a lot of them are terrorists.

\section{Do you believe that refugees are people who leave their homes with a reason?}

- Yes.

- I believe that they all leave their homes with a certain reason, but that this reason is not always justified.

- I believe they flee with a reason, but some flee for the wrong reasons.

- I believe they have a reason, but not all of them flee for the right reason.

- I believe they leave their homes for some reason. 
- I think they leave their homes with a reason.

- Yes, a majority.

- Yes and no - all of them, as well as we, would be much happier if they had stayed in their homes.

- Yes.

- Yes.

- Both yes and no....

- We cannot judge anyone, if we had not experienced this ourselves. Of course they leave their homes with a reason.

- I am not sure.

\section{Do you think that Europe has accepted the refugees adequately?}

- Depending from state to state, from place to place.

- I think they have been received adequately, within the possibilities of individual countries.

- I believe they were received adequately in the majority of countries.

- Europe should have directed them to their neighbouring countries, countries with very similar (if not the same) culture and customs to their own, the neighbouring and rich countries not affected by war.

- I think they have not been received adequately, Europe could have done better.

- No, I think too many have been received, and the accommodation is very poor in some places.

- Yes, Europe has adequately received the refugees.

- As the case may be, mainly yes - within the frame of one's own capabilities.

- In what sense?

- Some countries yes, some no... as with everything in life.

- I have not followed sufficiently in order to be able to say yes or no. I think no.

- Yes, as far as I followed the situation.

- And more than well.

\section{What would you change in receiving the refugees?}

- Depending on the locality where they were received, where this was not done properly, one should improve the organization, medical care, supply of food and other items, taking the register of the refugees, etc.

- I would not let them select the country to which they would like to go, but I would organize a receiving point in a state closest to their homeland.

- I would improve the organization of crossing the borders, with more control.

- I would introduce stricter control, ensure higher quality accommodation. 
- I would reduce the number of receipts, introduce stricter controls on borders and make the requirements for asylum seekers stricter.

- Nothing, in my opinion they have been provided with all the most basic needs.

- I think that migrants should have been accepted by someone else.

- Assimilate, not isolate - language learning program, learning the basics of history and culture of the receiving countries, work for the community and in the community.

- Method of socialization, and integration in the new life environment.

- I have not been following sufficiently in order to know what the situation is with them right now.

- I lack detailed information about the receipt.

- Show more empathy towards other people, this is not a planet just for some and not for the others.

- I would not accept so many refugees.

\section{How did you receive information related to refugees?}

- TV, newspapers, Internet.

- I received information mainly over the media.

- Media.

- I received information by means of media.

- Media.

- Media, more precisely via the Internet and TV.

- From the media, national and foreign ones.

- Printed and electronic media, social networks.

- Via media.

- Media.

- Media-mainly TV.

- Via the media. Sometimes also personally passing frequently near the Porin Hotel where they are accommodated.

- Newspapers, TV, Internet...

\section{Do you believe the media regarding information about the refugees?}

- No.

- I do not believe completely.

- I do not believe everything.

- I did not believe in everything that was reported.

- I don't trust the media, I think they manipulated a lot with the public opinion. 
- I have my own established opinion so that I believe them in some elements, and not in the others.

- Depending which media and in which situations.

- Mostly no, I obtain information from several national and foreign sources and by comparison make my own conclusions.

- No way.

- I receive information with a certain reserve and caution.

- Not entirely, as I do not believe completely in other information that has been presented to us.

- I do believe mainly. More than when other topics are in question.

- It is hard to believe anyone, especially the media.

\subsection{Survey}

For the requirements of this paper a survey was carried out on a sample of 200 respondents. The survey was sent via social networks. The respondents received only one question: "Is your attitude towards the refugees positive or negative."

Out of 200 respondents there were 138 of them with a positive answer, 53 gave a negative answer and 9 respondents said that they did not know.

\section{DO YOU SUPPORT THE REFUGEES}

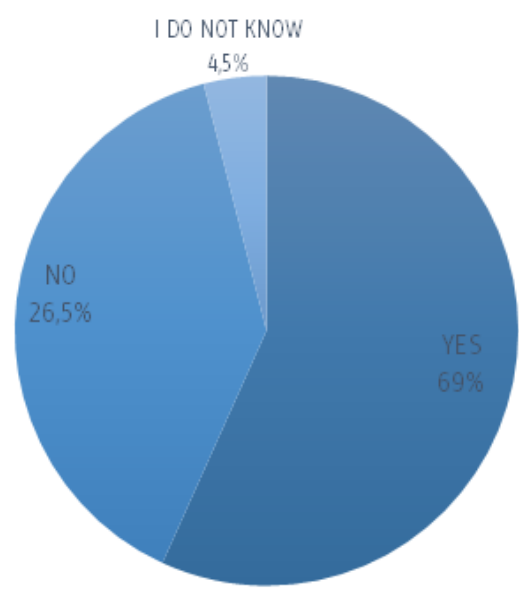

Figure 1. Answers to the question "Do you support the refugees?" 


\section{CONCLUSION}

After monitoring the arrival of migrants through the media during the recent years, and from the interview and the survey carried out for the requirements of this paper, it is very easy to conclude that there are different aspects and opinions regarding the problem of refugees that did not only divide some members of our community, but rather the countries of Europe as well. Whereas some benevolently look at unfortunate people who set out on a trip of thousands of miles with their bundles, not really knowing their purpose, others being sceptical, even arrogant lacking understanding, connecting the exiled inhabitants of the countries where mainly wars are fought, or the countries have been devastated and without perspective due to wartime suffering, with the growing influence of extremism and terrorism on the map of Europe.

Despite everything, Croatia has shown readiness to help, from public to civil sector, many humanitarian associations and numerous volunteers who got united in the one - to help the unfortunate people. Of course, without the media they would fail to be informed about this problem. However, from various sources, one can form their own judgement and see what has been really going on.

There is however a single fact: the refugee wave has not passed, it has just got a bit tired. Unfortunately, we are very far from clearing the cause of the misfortune of the countries in the East, which means that newcomers from that part of the world may be still expected. One thing is certain though - people do not run from the good things. The question is only, how much good they will find on their journey seeking a better life. 


\section{References}

1. Association of Municipalities in the Republic of Croatia (2018). "U zbrinjavanju migranata presudna je uloga lokalnih vlasti". Association of Municipalities in the Republic of Croatia. http://udruga-opcina.hr/hr/vijest/u-zbrinjavanju-migranata-presudna-je-ulogalokalnih-vlasti-2153 (visited on 30.05.2018).

2. Bohutinski, J. (2015). "Utopilo se 6702 izbjeglica, novi brod za spašavanje priprema se u Puli". Večernji list. 7 November 2015. https://www.vecernji.hr/vijesti/utopilo-se-6702izbjeglica-novi-brod-za-spasavanje-priprema-se-u-puli-1035804 (visited on 29.5.2018).

3. Croatian parliament (2017). Republic of Croatia National Security Strategy (NN 73/17). Zagreb, Croatia: Narodne novine.

4. European Parliament (2017). "Report on addressing refugee and migrant movements: the role of EU External Action (2015/2342(INI))". European Parliament. 22 February 2017 http://www.europarl.europa.eu/sides/getDoc.do?pubRef=-//EP//TEXT+REPORT+A82017-0045+0+DOC+XML+V0//HR) (visited on 29.05.2018).

5. Institute for the Development of Education (2015). "Kako integrirati izbjeglice u sustav visokog obrazovanja?". Institute for the Development of Education. 25 September 2015. http://iro.hr/hr/o-nama/odnosi-s-javnoscu/priopcenja-za-javnost/view-press-9350/ (visited on 22.5.2018.)

6. Mikac, R. \& Dragović, F. (2017). Masovne migracije: izazovi, posljedice i put naprijed. Forum za sigurnosne studije, 1 (1), 130-152. Retrieved from https://hrcak.srce.hr/198071

7. Tadić, T., Zajović, M. (2017). "Balkanska ruta: izbjeglice, krijumčari i političari". Mreža antifašistkinja Zagreb. 19 January 2017. http//www.maz.hr/2017/01/19/balkanska-rutaizbjeglice-krijumcari-i-politicari/ (visited on 28.5.2018).

8. Tomašić, Ž. (2015). "Civilno društvo u Hrvatskoj ". Razvojna organizacija zaštite potrošača. 19 December 2015. https://www.rozp.hr/index.php/14-intermezzo/248-civilno-drustvou-hrvatskoj (visited on 27.5.2018).

9. Institute for Migrations and Nationalities (2016). "Integracija migranata u Europskoj uniji s osvrtom na Hrvatsku: Strateška polazišta instituta za migracije i narodnosti". Institute for migrations and nationalities. February 2016. http://www.imin.hr/c/document_library/ get_file?uuid=8aa80cd9-f191-4f01-b4cb-a302b8d14a0d\&groupld=10156 (retreived on 27.05.2018.) 